\title{
Article \\ Optimizing the Formation of Hydraulic Cylinder Surfaces, Taking into Account Their Microrelief Topography Analyzed during Different Operations
}

\author{
Volodymyr Dzyura * D and Pavlo Maruschak \\ Department of Motor Vehicles, Ternopil Ivan Puluj National Technical University, 46001 Ternopil, Ukraine; \\ maruschak.tu.edu@gmail.com \\ * Correspondence: volodymyrdzyura@gmail.com
}

Citation: Dzyura, V.; Maruschak, P. Optimizing the Formation of

Hydraulic Cylinder Surfaces, Taking into Account Their Microrelief Topography Analyzed during Different Operations. Machines 2021, 9, 116. https://doi.org/10.3390/ machines9060116

Academic Editor: Francisco J. G. Silva

Received: 10 May 2021

Accepted: 8 June 2021

Published: 10 June 2021

Publisher's Note: MDPI stays neutral with regard to jurisdictional claims in published maps and institutional affiliations.

Copyright: (C) 2021 by the authors Licensee MDPI, Basel, Switzerland. This article is an open access article distributed under the terms and conditions of the Creative Commons Attribution (CC BY) license (https:/ / creativecommons.org/licenses/by/ $4.0 /)$.

\begin{abstract}
Causes of the in-service damage to hydrocylinder liners were investigated, and the requirements to their working surfaces were systematized. Roughness parameter Ra was found not to provide a precise estimate of the surface quality because its reduction did not affect surface microgeometry. Additionally, the surface quality was assessed by the Abbott-Firestone curve during the finishing operation. The optimized manufacturing technology for obtaining hydrocylinder liners was offered based on having the required microgeometry and surface quality provided by cutting operations. The quality and service characteristics of internal surfaces of hydrocylinder liners were improved by changing technological operations. In particular, the semi-finish turning was chosen to provide for the surface roughness parameter Ra within $6.3-8.0 \mu \mathrm{m}$ and the roughness pitch parameter $\mathrm{S}$ within $0.4-0.6 \mathrm{~mm}$ and homogeneous surface structure. The finishing rolling was replaced by burnishing to form a regular microrelief.
\end{abstract}

Keywords: hydrocylinder; roughness; cylindrical surface; parameter; quality; roughness; cutting; rolling; technological process; operation; Abbott-Firestone curve

\section{Introduction}

Hydrocylinders are the main actuating elements of construction, road, and service machinery, and other special equipment. They are widely used in MTZ-50/80/90, K-700, K 744, T-25, DT-75, DZ-42, DZ-162, T-16, and TTZ-60.11 tractors, PKU-0.8 SNU-550, and PBM-800 wheel loaders, combines, drills, excavators, motor graders, KTA-18, KTA-18E, KTA-25, KTA-25E, and KTA-32 truck cranes, AGP-27 auto-hydraulic lifts, garbage trucks, and many other machines. Their designs differ in functional purpose [1], but the mode of action and manufacturing technology are almost identical.

Even though the designs of hydrocylinders are very similar, many contemporary scientific publications are dedicated to studying their geometric parameters and modes of operation [2], assessment of their technical condition [3], analysis of the cylinder liner surface microstructure [4], and manufacturing technology for obtaining hydrocylinder elements [5]. One of the most essential elements of the hydrocylinder is the liner. Its internal cylindrical surface serves as the working surface, which comes into contact with the rod surface sealed by a rubber cuff, which performs a reciprocating motion inside the cylinder [6-8].

The working surfaces of hydrocylinder liners are very hard to machine. This is because such working surfaces are deep holes, in which the length-to-diameter ratio exceeds $L / D>5$ [9-14]. During their manufacture, the tool access to the machined surfaces is hindered. Simultaneously, ensuring the specified parameters of such working surfaces remains an essential technical task of the machine-building industry. The typical processing technology applied to the internal cylindrical surfaces consists of two groups of operations: turning operations that provide for the necessary shape and size of the surface and plastic 
deformation operations that provide for the required physical and mechanical properties of the surface.

In some works, the methods for estimating the roughness parameter in different technological operations were subjected to a comprehensive analysis $[15,16]$. The influence of turning methods applied to cylindrical specimens from steel 1Cr18Ni9Ti on the resulting surface roughness parameters was considered in [17]. Profilograms of test specimens in ten cross-sections were analyzed, and graphs of surface roughness versus cutting speed, feed and depth were plotted. In [18], theoretical dependences were proposed that linked surface roughness to the cutting mode elements, mainly the feed. However, the obtained models were empirical, and determining their parameters for making the surfaces of hydrocylinder liners requires further research.

A simulation model of the surface profile obtained by turning with known vibration characteristics was proposed in [19]. It was proved that radial vibrations change the surface roughness much more than tangential or axial vibrations. The way the surface quality and cutting force were affected by the cutting tool's geometric parameters and the workpiece hardness during finishing was summarized in [20].

The imperfect nature of roughness parameters used to assess the surface quality was analyzed in [21]. The authors studied and compared surfaces that differed in microgeometry but had the same roughness. The Abbott-Firestone curve [22-25] and $R_{k}$ parameter have become widely used to evaluate the relationship between machine parts' performance properties and surface roughness. Peculiarities of estimating the surface condition using the Abbott-Firestone curve were described in [26,27]. In particular, the authors found the surface integrity to be the relationship between the required functional properties of the surface and the change in the properties of the new surface. The surface can be evaluated using two basic properties: the spatial arrangement of the surface (surface roughness) and the physicochemical properties of the surface layer.

Plastic deformation of the surface is common during finishing the internal cylindrical surfaces of deep holes. Moreover, optimizing the plastic deformation conditions is a significant engineering and scientific task [28]. In particular, the authors proposed using the dynamic hardening of long rod parts during technological operations of finishing.

In some works, the influence of regular microrelief on the service properties of friction surfaces was generalized [29]. The basic patterns of ensuring tightness and wear resistance of moving "metal-rubber" couplings, which perform the relative reciprocating motion, were established. The optimal modes and parameters that ensure the minimum surface roughness and regular microrelief of type IV (mesh microrelief) were substantiated. Under friction conditions, the microrelief's type and shape had a much more significant effect on the tightness than the surface roughness. In [29], the surface roughness $R a=8 \mu \mathrm{m}$ with the irregularities pitch $S=0.712 \mathrm{~mm}$ was recommended, which corresponds to the semi-finish turning and provides high durability. In the presence of microrelief, such surface roughness provides for the maximum tightness and wear resistance of the movable "rubber-metal" coupling.

Technological heredity is an essential factor in the analysis of surface quality indicators [30]. It was investigated in [31] to optimize the machining of parts of hydrocylinder liners. Additionally, the influence of cylinder liners' deviation from roundness on their operational reliability was evaluated. Some operations were found to deteriorate the accuracy of the part. Therefore, their exclusion from the structure of technological operations was proposed.

The purpose of this research was to optimize the manufacturing technology for obtaining the working surface of hydrocylinders, taking into account its microrelief topography analyzed during various technological operations.

\section{Relationship between Hydrocylinders' Surface Parameters and Features of Their Wear}

We suggested that the numerical values of the height parameters of the roughness can not be an unambiguous assessment of surface quality. The condition of the surface 
should also be assessed visually using 3D profilometry, as the numerical values of the parameter Ra provide a generalized idea of the condition of the surface. Therefore, the quality of the working surfaces of machine parts must be further assessed using their performance properties. This is done to prevent cases where the height parameters of the surface roughness Ra will be within the limits allowed by the designer, and the performance properties will be unsatisfactory.

The shape of hydrocylinder liners is subject to stringent accuracy requirements. In particular, deviations from straightness in the longitudinal direction and deviations from roundness in the cross-section are prohibited. This is because the operation of hydrocylinders does not allow for the flow of working fluid from one cavity to another. Technical requirements for hydrocylinders are regulated by GOST 16514-96 [14].

It is noteworthy that difficult operating conditions, aggressive environments, and high-amplitude alternating loads distort the initial microrelief of the liner's working surface, which impairs its performance even with uniform wear. However, under operating conditions, hydrocylinder liners are usually characterized by uneven surface wear due to the localization of friction processes. Hydrocylinder liners are characterized by faults unacceptable during operation, some of which are caused by the surface condition of the hydrocylinder liner (Table 1).

Table 1. Types of hydrocylinder failures caused by suboptimal microgeometry, surface roughness, kinematic, and force factors.

\begin{tabular}{lll}
\hline \multicolumn{1}{c}{ Fault Type } & \multicolumn{1}{c}{ Fault Reason } & \multicolumn{1}{c}{ Consequences } \\
\hline $\begin{array}{l}\text { Deviation of } \\
\text { microgeometry } \\
\text { and surface } \\
\text { roughness }\end{array}$ & Non-optimal working surface roughness & $\begin{array}{l}\text { An increase in friction coefficient, the occurrence of excessive longitudinal } \\
\text { and transverse loads, increase in wear intensity. }\end{array}$ \\
\cline { 2 - 3 } & Non-optimal working surface geometry & $\begin{array}{l}\text { Increase in wear intensity and rapid wear, impaired load-bearing and } \\
\text { sealing properties. }\end{array}$ \\
\hline $\begin{array}{l}\text { In-service and } \\
\text { kinematic } \\
\text { damage }\end{array}$ & \begin{tabular}{l} 
Imperfect lubrication of friction surfaces \\
\cline { 2 - 3 }
\end{tabular} & $\begin{array}{l}\text { Increase in friction coefficient between the rod and the cylinder liner. } \\
\text { Increased friction force and elastic deformations outside the friction zone. } \\
\text { In reverse motion, this changes the distribution of contact loads and } \\
\text { causes additional plastic deformation of the contact zone. }\end{array}$ \\
\cline { 2 - 3 } & $\begin{array}{l}\text { Significant differences in the operational value of } \\
\text { the rod projection }\end{array}$ & $\begin{array}{l}\text { Increased contact shear deformations in the contact zone, which causes } \\
\text { structural degradation of the liner material. } \\
\text { Increased degradation of the cylinder liner material, accumulation of } \\
\text { micro- and macrodefects in the surface layer, which causes the activation } \\
\text { of diffusion, adsorption, and chemisorption interaction of the friction } \\
\text { surface. }\end{array}$ \\
\hline $\begin{array}{l}\text { Force factors } \\
\text { Misalignment between a rod and a liner owing }\end{array}$ & $\begin{array}{l}\text { "liner-rod" system } \\
\text { Deflections/shears in the "liner-rod" system. }\end{array}$ \\
\cline { 2 - 3 } & Rod distortions (technological distortions). & $\begin{array}{l}\text { Misalignment of the "liner-rod" system, which leads to plastic } \\
\text { deformations accumulated in the liner and rod walls, followed by } \\
\text { jamming of the rod. }\end{array}$ \\
\hline
\end{tabular}

It follows from the above classification that the manufacturing technology for obtaining the hydrocylinder liner surface is crucial for the microgeometry of the "rodhydrocylinder" friction pair. To a large extent, it forms the kinetics of fatigue microdamage accumulation and wear of friction surfaces. Microgeometry parameters indirectly affect the contact pressures in the near-surface layers of the hydrocylinder liner and the temperature and force conditions of its operation. Also, they determine the wear type of parts and the possibility of burrs or chips being formed on the hydrocylinder wall, which, along with other factors, account for the appearance of the oil film.

\section{Objects and Methods of Research}

The object of research was the KS-4574.63.900 hydrocylinder for telescoping (releasing) the KTA-25 truck crane beam, manufactured at the Drohobych Truck Crane Plant (Drohobych, Ukraine) (Figure 1). 


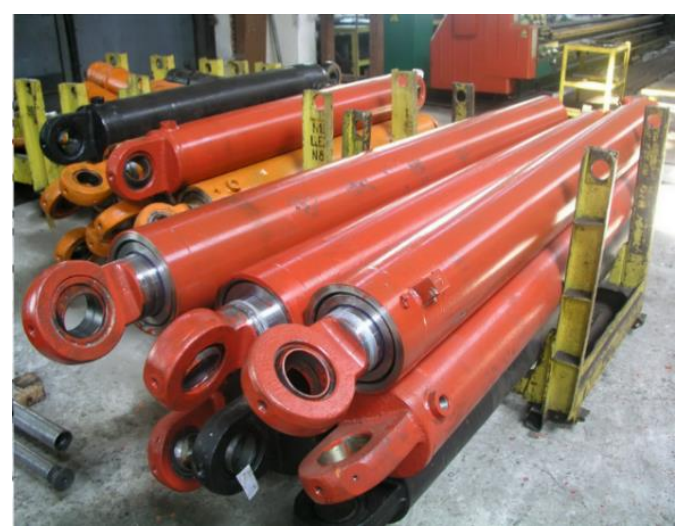

(a)

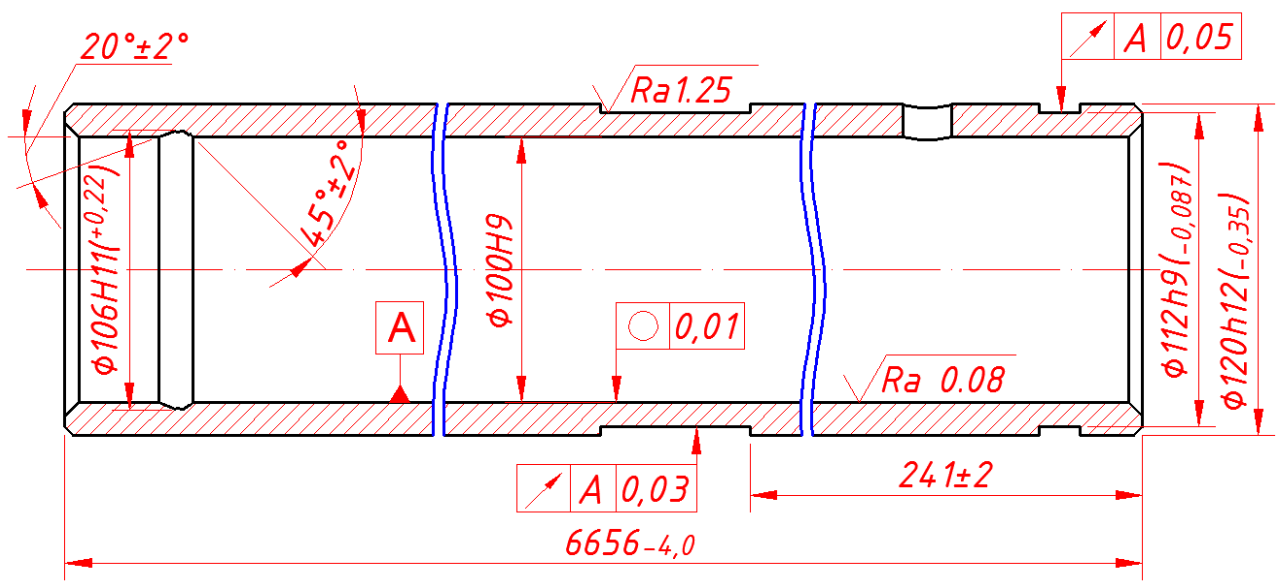

(b)

Figure 1. KS-4574.63.900-03.00 plunger hydrocylinder for telescoping the truck crane beam, manufactured at Drohobych Truck Crane Plant (a) and some technical requirements for its cylinder liner (b).

The workpieces for hydrocylinders manufactured by DTCP are seamless cold-drawn pipes honed or polished following ISO H8 and welded cold-drawn pipes processed on the inner diameter following ISO H9 or ISO H10. Steels of the following grades are used in the production of hydrocylinders: St 52, St 52.3, and St E 460 made in Germany following DIN 2393-1994 and DIN 17102. Ukrainian counterparts of St 52 and St 52.3 are steels 17G1S and 17GS, and that of St E 460 is steel 18G2AFps.

Hydrocylinders were made of steel, which has the following chemical composition: $\mathrm{C}=0.22 ; \mathrm{Si}=0.10-0.55 ; \mathrm{Mn}=1.60 ; \mathrm{P}=0.035 ; \mathrm{S}=0.035 ; \mathrm{Al}=0.020$, which has $\sigma_{\mathrm{us}}=570 \mathrm{MPa}$; $\sigma_{\mathrm{ys}}=470 \mathrm{MPa} ; \delta=15 \%$.

The geometric parameters of the hydrocylinder are presented in Table 2.

Table 2. General characteristics of the hydrocylinder for telescoping the truck crane beam.

\begin{tabular}{cccccc}
\hline Hydrocylinder & $\begin{array}{c}\text { Piston Diameter, } \\
\mathbf{m m}\end{array}$ & $\begin{array}{c}\text { Rod Diameter, } \\
\mathbf{m m}\end{array}$ & $\begin{array}{c}\text { Piston } \\
\text { Stroke, } \mathbf{m m}\end{array}$ & $\begin{array}{c}\text { Max. Pressure in the } \\
\text { Hydraulic System, MPa }\end{array}$ & $\begin{array}{c}\text { Weight, } \\
\text { kg }\end{array}$ \\
\hline KS-4574.63.900-03.00 & 100 & 80 & 6000 & 25 & 411.8 \\
\hline
\end{tabular}

To conduct the research, specimens in the form of cylindrical rings were obtained from the cylinder liner (Figure 2a) using the technological operations of roughing, semi-finishing, and finish rolling. A $20 \times 12 \mathrm{~mm}$ fragment (Figure $2 \mathrm{~b}$ ) was excised from each ring for testing on a Zygo NewView 6200 white scanning interference microscope. Additionally, a spatial image of the surface roughness profile was obtained. As shown in Figure $2 a$, the microscope produces three images of the surface roughness profile. 


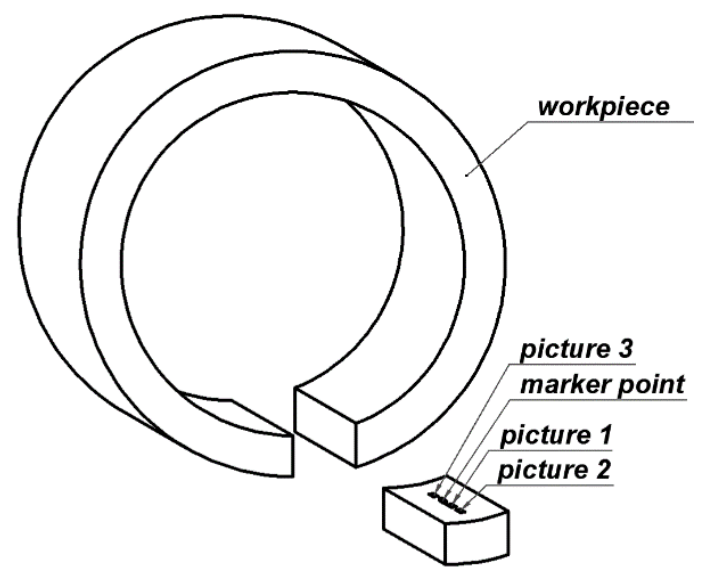

(a)

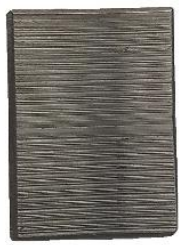

I

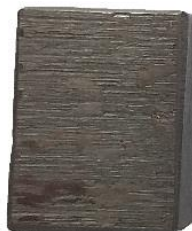

II

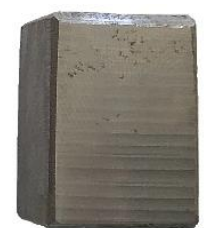

III

(b)

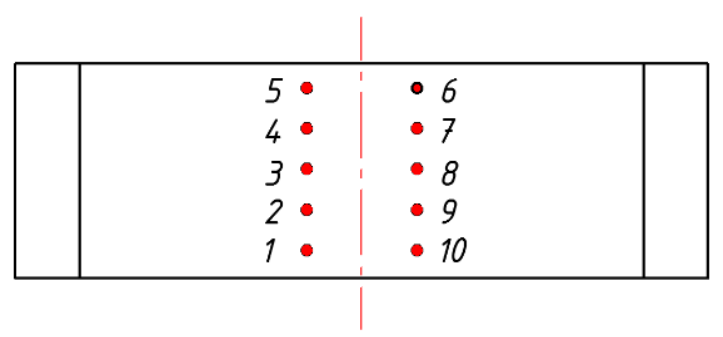

(c)

Figure 2. Template cutting scheme (a); photos of the template surface (b) after different types of machining: I-after roughing; II—after semi-finishing; III—after finish rolling; (c) a scheme for measuring surface hardness.

The template roughness was monitored by the NewView 7300 optical interferometer manufactured by Zygo (Lambda Photometrics Ltd., Harpenden, Hertfordshire, United Kingdom). Hardness was measured by the Rockwell method (scale B) on the TP5006-02 hardness tester. The previous load was $98.07 \mathrm{~N}$, and the total load was $980.7 \mathrm{~N}$. The ball diameter was $1.588 \mathrm{~mm}$. Hardness was measured at ten points spaced in $6 \mathrm{~mm}$ increments. The small sample theory was used to estimate the hardness scatter. The specimen surfaces were examined on the EVO-40XVP scanning electron microscope with the INCA Energy 350 spectral microanalysis system.

\section{Manufacturing Technology Analysis}

The tight connection between the hydrocylinder rod seal and the working surface of the hydrocylinder liner was ensured by surface treatment. The structure and content of the technological operations for manufacturing hydrocylinder liners are shown in Table 3.

Table 3. Structure of technological operations for manufacturing hydrocylinder liners shown on an example of the KS4574.63.900 hydrocylinder for releasing the KTA-25 truck crane beam.

\begin{tabular}{|c|c|c|c|c|c|c|c|c|}
\hline $\begin{array}{c}\text { Operation } \\
\text { No. }\end{array}$ & $\begin{array}{c}\text { Groups of } \\
\text { Technological } \\
\text { Operations }\end{array}$ & $\begin{array}{l}\text { Number of } \\
\text { Transitions }\end{array}$ & $\begin{array}{c}\text { Inner } \\
\text { Diameter } \\
D, \mathrm{~mm}\end{array}$ & $\begin{array}{c}\text { Surface Roughness According } \\
\text { to Technical Documentation } \\
\qquad R a, \mu \mathrm{m}\end{array}$ & $\begin{array}{c}\text { Location } \\
1\end{array}$ & $\begin{array}{c}\text { Location } \\
2\end{array}$ & $\begin{array}{c}\text { Location } \\
3\end{array}$ & Average \\
\hline 1 & \multirow{2}{*}{ Roughing } & 1 & Ø94Н11 & 20 & & & & \\
\hline 2 & & 1 & Ø98.3Н11 & 10 & 7.36 & 7.48 & 9.84 & 8.22 \\
\hline 3 & \multirow{2}{*}{ Semi-finishing } & 1 & Ø99.3Н11 & 5 & & & & \\
\hline 4 & & 1 & Ø99.5Н11 & 5 & 7.44 & 4.86 & 8.8 & 7.03 \\
\hline 5 & Finishing & 1 & Ø100Н9 & 0.32 & 0.16 & 0.16 & 0.24 & 0.18 \\
\hline
\end{tabular}

The surface peculiarities at different stages of the technological process were analyzed by comparing the hardness. The surface hardening intensity and the hardness scatter of the hydrocylinder liner after various technological operations are shown in Table 4. 
Table 4. Hardness value, HRB (for 10 measurements) on each technological operation.

\begin{tabular}{|c|c|c|c|c|c|c|c|c|c|c|c|c|}
\hline \multirow{2}{*}{$\begin{array}{l}\text { Operation } \\
\text { No. }\end{array}$} & \multirow{2}{*}{$\begin{array}{c}\text { Groups of } \\
\text { Technological } \\
\text { Operations }\end{array}$} & \multirow{2}{*}{$\begin{array}{c}\text { Inner } \\
\text { Diameter } \\
D, \mathrm{~mm}\end{array}$} & \multicolumn{10}{|c|}{$\begin{array}{l}\text { Hardness Value, HRB } \\
\text { for } 10 \text { Measurements }\end{array}$} \\
\hline & & & 1 & 2 & 3 & 4 & 5 & 6 & 7 & 8 & 9 & 10 \\
\hline 2 & Roughing & Ø98.3Н11 & 77 & 80 & 77 & 78 & 70 & 77 & 81 & 77.5 & 79.5 & 85.0 \\
\hline 4 & Semi-finishing & Ø99.5Н11 & 80 & 75 & 77 & 76.5 & 77 & 83 & 85.5 & 75.5 & 82.5 & 83.0 \\
\hline 5 & Finishing & Ø100H9 & 91.5 & 94.0 & 95.0 & 94.0 & 94.5 & 93.5 & 94.5 & 91.5 & 93.5 & 94.5 \\
\hline
\end{tabular}

Using the small sample theory [31], we determined the mean hardness of the treated specimen surface after roughing $M(\mathrm{HRB})=79.4$ units, with scatter being $D(\mathrm{HRB})=5.5$, after semi-finishing $M(\mathrm{HRB})=81.8$ units, with scatter being $D(\mathrm{HRB})=6.8$, and after finishing $M(\mathrm{HRB})=93.8$ units, with scatter being $D(\mathrm{HRB})=0.7$. Thus, observed a slight increase in hardness and its scatter, which indicated the negative impact of semi-finishing on the stability of the physicomechanical properties of the surface. The finishing operation of rolling provided for the necessary physical and mechanical properties of the treated surface and significantly reduced the scatter of the surface hardness values.

As is seen from the photos showing test specimen surfaces (Figure 3), the roughing followed by semi-finishing produced a non-homogeneous structure on the hydrocylinder liner surface (Figure 3b), which was then smoothed out by finish rolling. This was also confirmed by $3 \mathrm{D}$ images of the roughness profile of this surface (Figure 4), which showed plastic deformation zones that alternated with areas typical of turning. A non-homogeneous structure obtained by turning may indicate incorrectly selected cutting modes, which led to a nodule formed on the surface, which was then destructed by processing. Significantly, the roughness pitch parameter $S$ was in the range of $0.4-0.6 \mathrm{~mm}$, which is optimal in accordance with the recommendations [29]. According to the electron microscopic analysis of template surfaces, each stage of processing accounted for certain morphological features of the surface morphology, namely:

Rough turning, Figure 4a, caused the formation of deep lines on the surface, which can be considered a consequence of intermittent cutting. The uneven surface relief was a negative factor caused by the vibration of the cutting tool, the workpiece, and machine parts. This reduced the workpiece surface quality.

Semi-finishing resulted in the surface with a pronounced effect of plastic deformation. There were noticeable scaly tears on the surface. Their height indicated a low temperature in the treatment zone. This surface-forming mechanism also evidenced the cyclical interaction between the tool and the workpiece surface. Plastic deformation causes the strengthening of the surface layer and structural and mechanical heterogeneity of surface properties at the micro-level.

Finishing occurred due to the tool and treated surface coming into contact by their roughness tops, the bearing area of which was small. The surface looked relatively smooth, covered with small unidirectional lines. This was due to significant pressures on the contact surface that exceeded the yield strength of the material and caused the intense plastic deformation of roughness, followed by its smoothing. In parallel, the contact area between the tool and the treated surface increased. Under such conditions, the surface layer of the metal was significantly strengthened, which increased the surface resistance to plastic deformation. Thus, the roughness value was stabilized. 


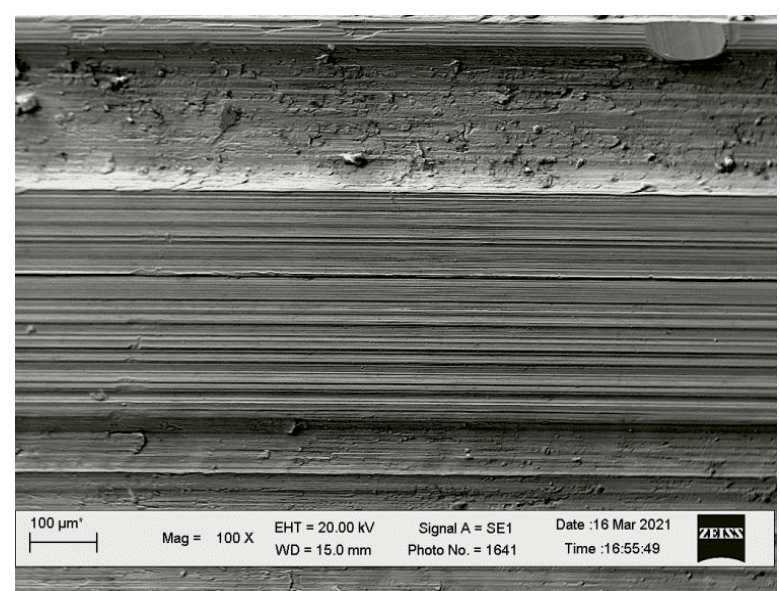

(a)

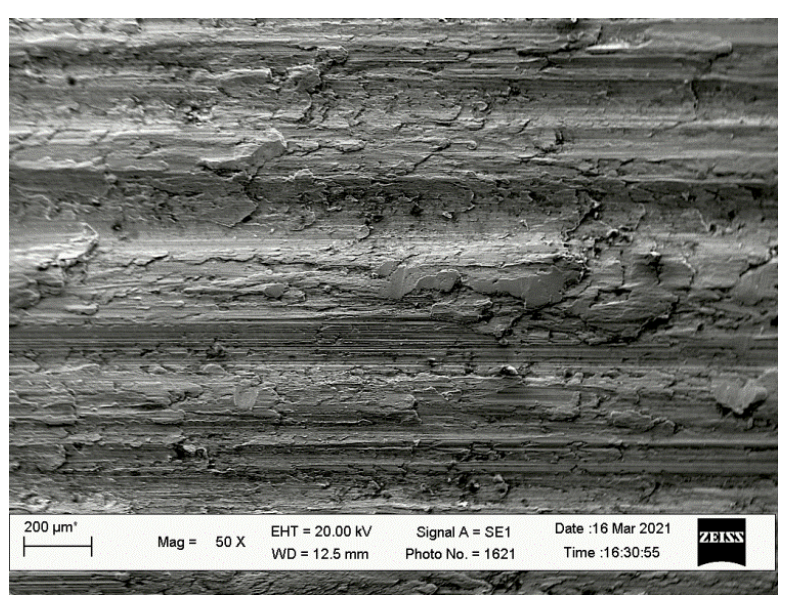

(c)

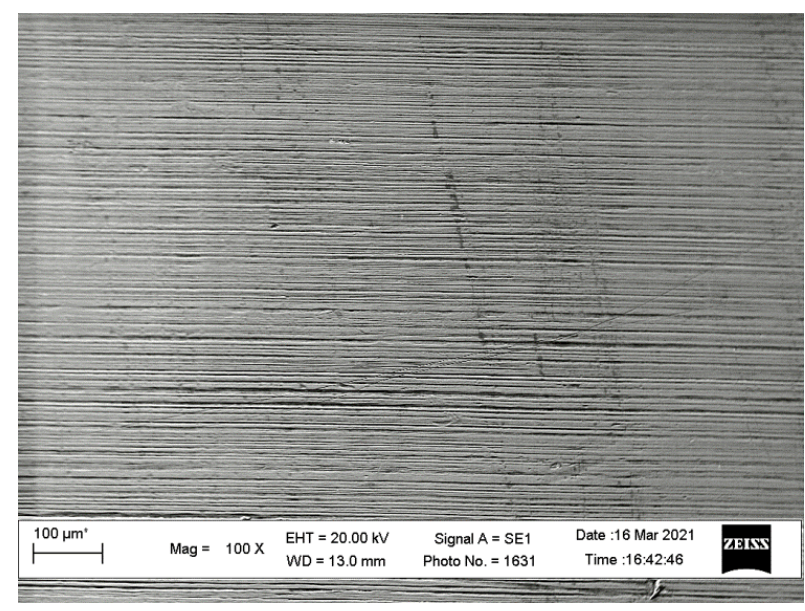

(e)

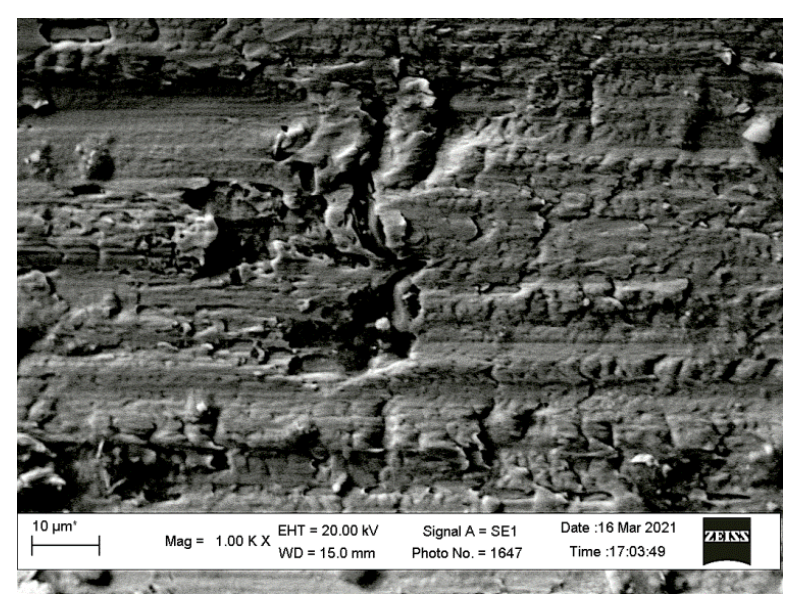

(b)

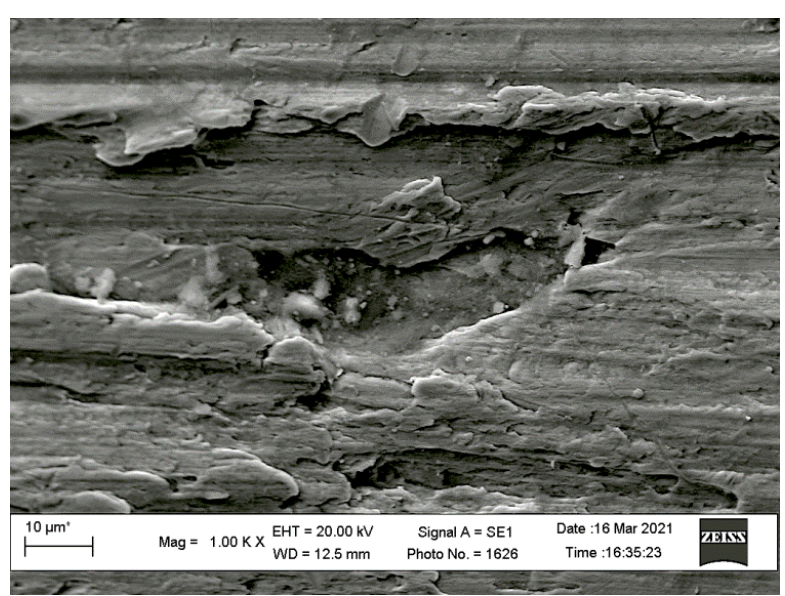

(d)

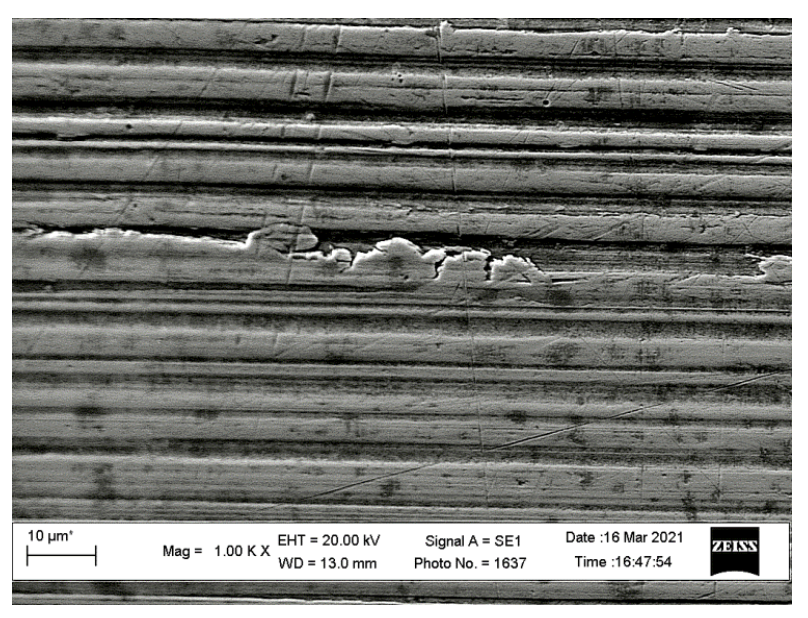

(f)

Figure 3. Images of specimen surfaces at 100× magnification: (a,b)—after roughing; (c,d)—after semi-finishing; (e,f)—after finishing. 

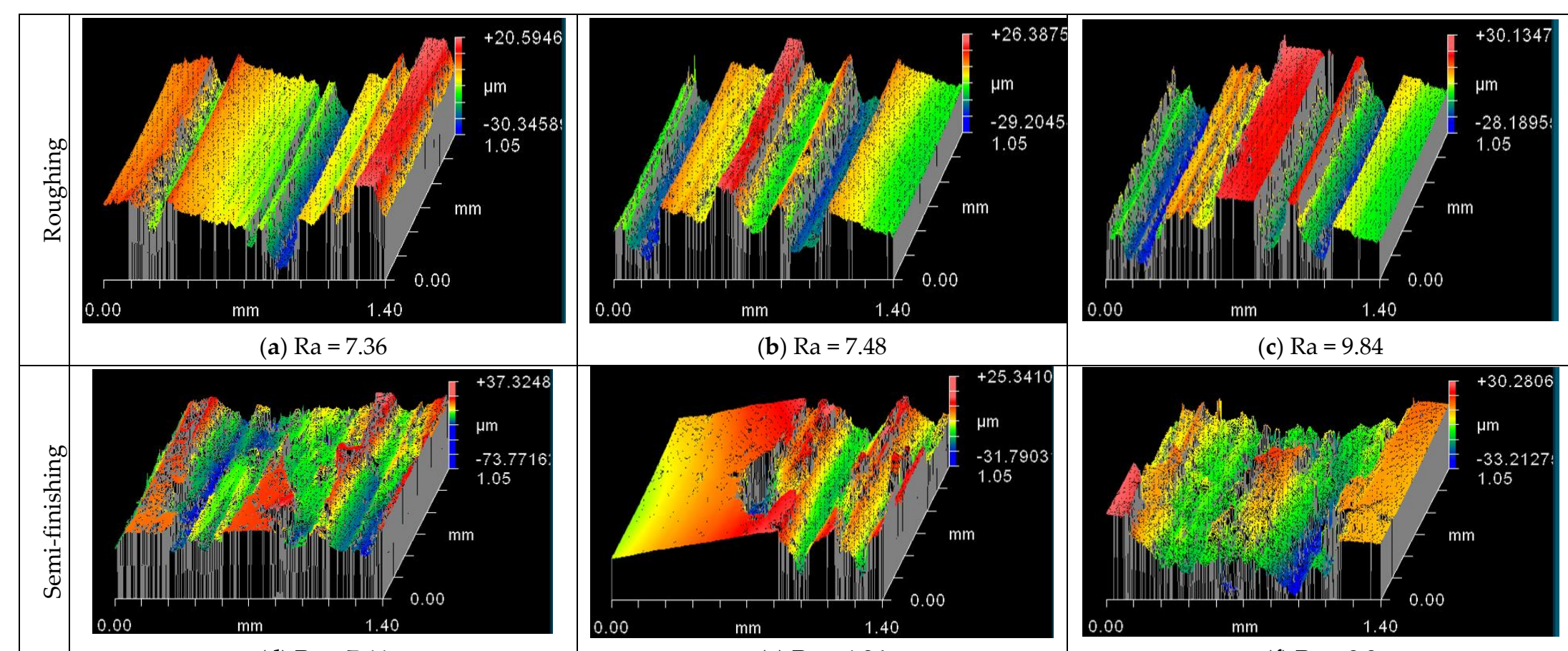

(b) $\mathrm{Ra}=7.48$

(c) $\mathrm{Ra}=9.84$
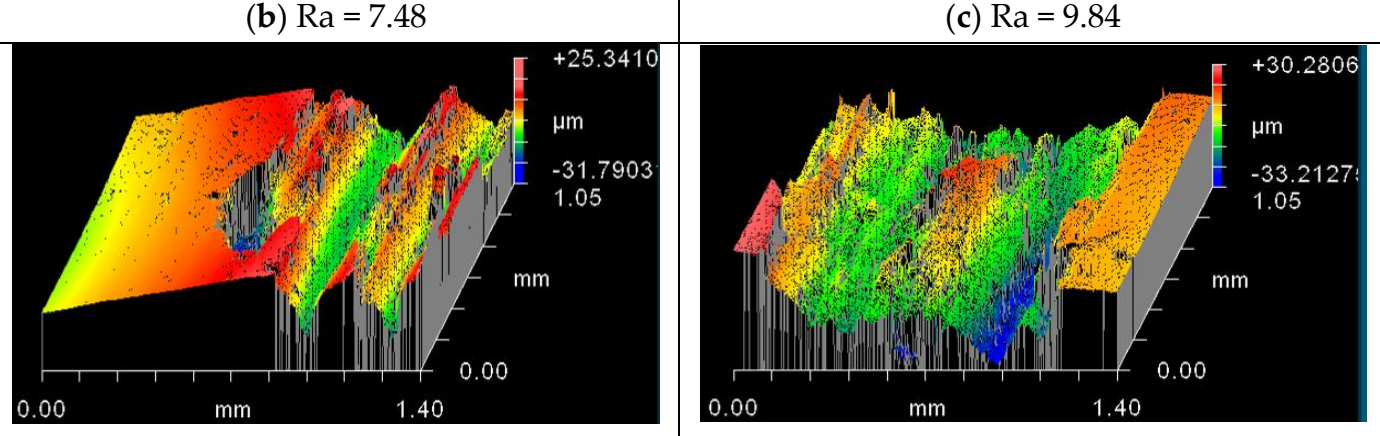

(d) $\mathrm{Ra}=7.44$

(e) $\mathrm{Ra}=4.86$

(f) $\mathrm{Ra}=8.8$

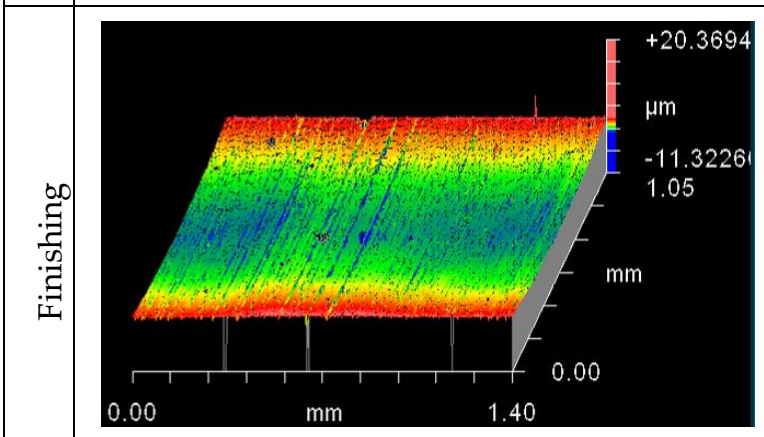

(g) $\mathrm{Ra}=0.16$
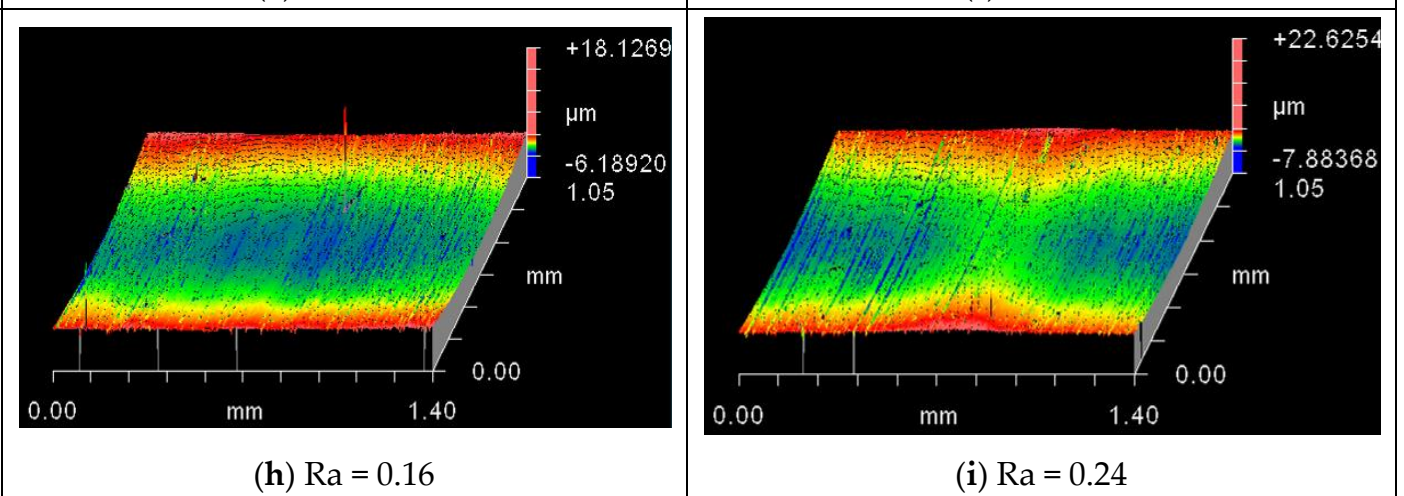

Figure 4. 3D-photos of test specimen surfaces $(1.4 \times 1.5 \mathrm{~mm})$. 
One can clearly see from Figure 3d that the finish rolling did not eliminate the deep grooves obtained by the previous machining. Besides, during the operation of the cylinder liner, these defects will become the localized areas of in-service damage.

\section{3-D Profilometry}

The nature of the interaction between the cutter surface and the treated surface is shown in 3-D profiles (Figure 5).

Rough turning - there are deep "gaps" on the surface, which contain stair-like protrusions and depressions with relatively sharp edges.

Semi-finish turning — deformed surface areas are noticeable, with transitions from small holes to smoothed surfaces.

Finish turning - traces of contact between the tool and the workpiece are noticeable, which occurs in the form of "blue spots" projection. This indicates smoothing with a periodic separation from the treated surface.

Thus, the relief formed makes it possible to change the surface relief and its hardness. Under optimal conditions, this ensures guaranteed wear resistance of the workpiece and the wear process uniformity along the entire length of the workpiece.

\section{Discussion of Findings}

The Abbott-Firestone diagram (ISO 4287 1996) was constructed for the surface obtained after finishing (Figure 6), which corresponded to the profilogram (Figure 5h). The curve describes the filling length-to-estimated length ratio, with the specified cut depth expressed in \%. Simultaneously, a low value of the $R_{p k}$ parameter and a decrease in the $M_{r 1}$ value expressed in \% indicate an elevation of the material proportion above the profile midline (depression), which preconditions a significant contact area of the surface. The slope at the beginning of the curve indicates profile peaks, which cause the wear of seals, and the slope at the end of the curve indicates profile depressions, which are reservoirs of oil.

Standard [13] provides for a dependency that determines the amount of oil produced on the surface

$$
V_{o}=\frac{R_{v k}\left(100-M_{r 2}\right)}{200}
$$

where $V_{o}$ is the volume that contains oil, $\mathrm{mm}^{3} / \mathrm{cm}^{2}$.

We calculated the amount of oil that will be produced on the cylinder liner surface using the values obtained from the diagram (Figure 6)

$$
V_{o}=\frac{0.94(100-88.14)}{200}=0.05574 \mathrm{~mm}^{3} / \mathrm{cm}^{2}
$$

The limit value according to [14] is $0.05 \mathrm{~cm}^{3} / \mathrm{m}^{2}$.

The maximum value of oil that will be retained on the hydrocylinder liner surface satisfied the conditions given in standard [14] but was close to the limiting value. From a practical point of view, this means that after a specific time, depending on the operating conditions, the amount of oil retained on the liner surface will be less than necessary to ensure standard operating conditions.

It is evident that the obtained structure and quality parameters of the inner cylindrical surface of the hydrocylinder liner decreased its service life due to the loss of tightness in the connection between the rod sleeve and the working surface of the hydrocylinder liner. Moreover, the surface quality parameters, such as roughness, accuracy, physical, and mechanical parameters were high enough, and their values met the technical requirements for the working surfaces of hydrocylinder liners. However, these parameters were not optimal for the "metal-rubber" coupling that performs relative movements [29-35].

Figure 7 shows the schemes of interaction between surfaces obtained by: (a) the basic technology, which provided for the low roughness parameters, but contained a significant number of micro defects; (b) the formation of a regular microrelief. 


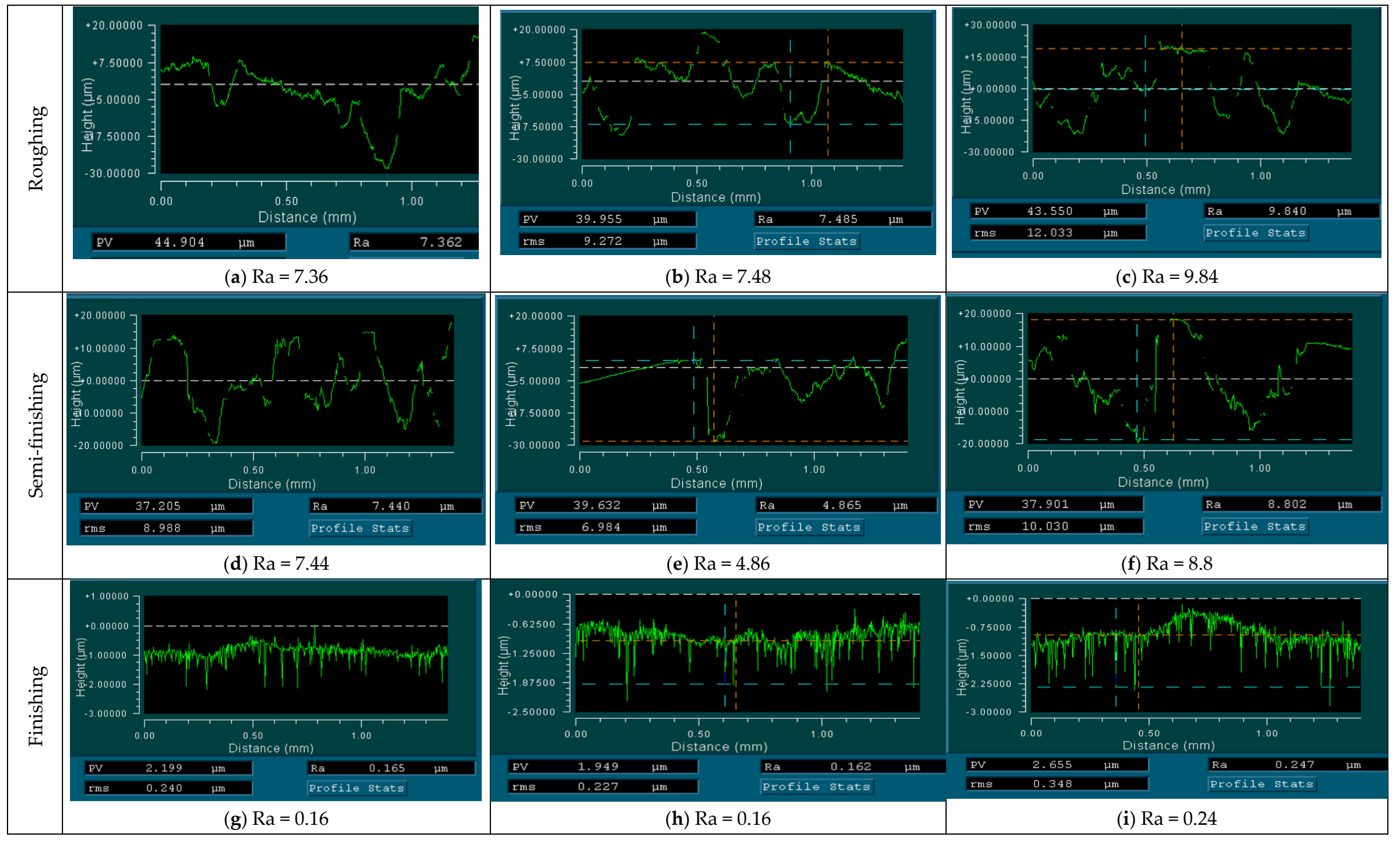

Figure 5. Profilograms of test specimen surfaces $(1.4 \times 1.5 \mathrm{~mm})$. 


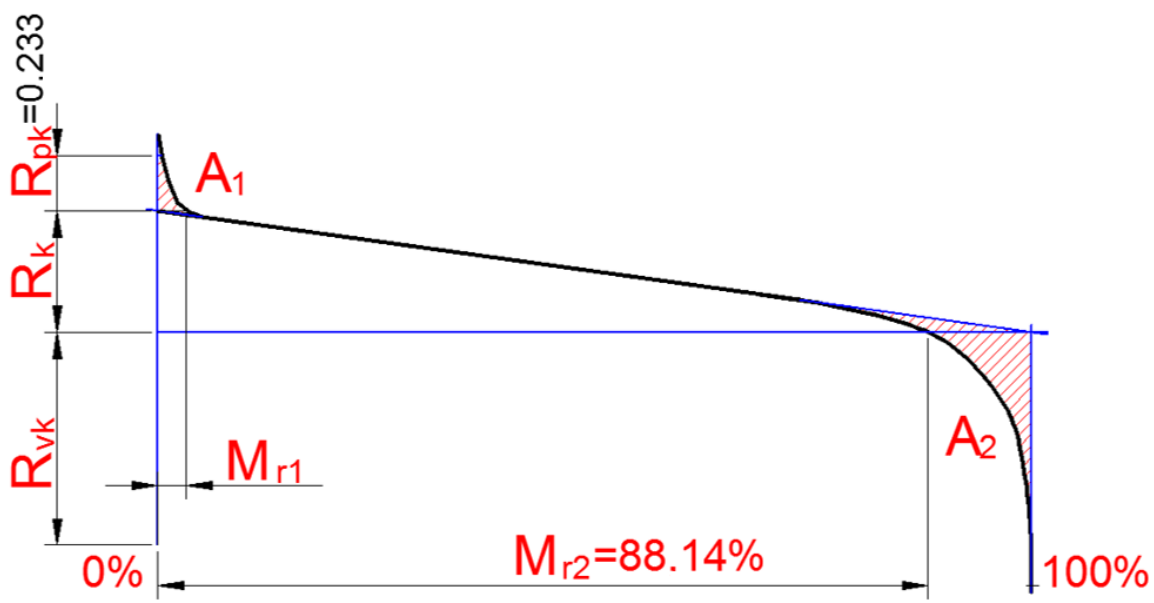

Figure 6. Abbott-Firestone diagram for the inner cylindrical surface of the specimen obtained after finish rolling: $R_{p k}$-reduced peak height; $R_{k}$-profile core depth; $R_{v k}$-reduced valley depth; $M r_{1}$-percentage of the material separated by a line that separates the peaks from the profile core; $M r_{2}$-percentage of the material separated by a line that separates the valley from the profile midline.

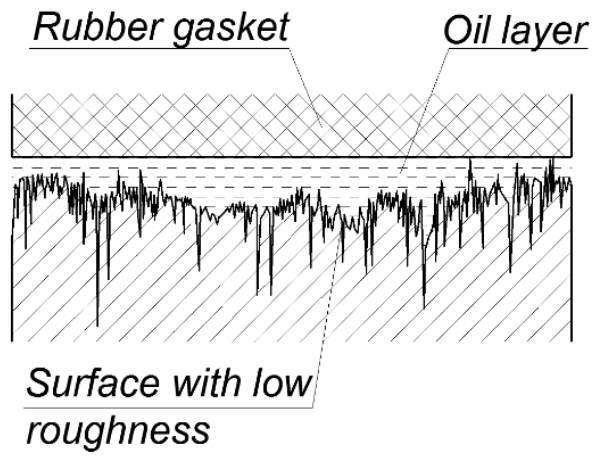

(a)
Rubber gasket Oil layer

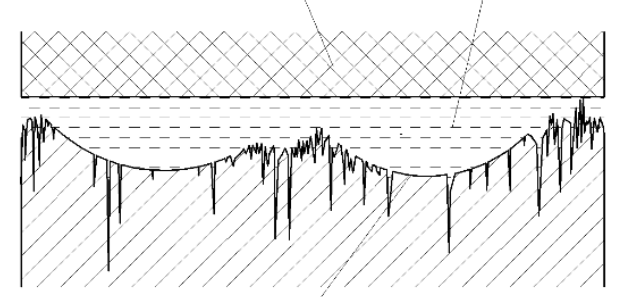

Surface with regular microrelief

(b)

Figure 7. Surface interaction schemes: (a) surface with low roughness and micro defects; (b) surfaces with regular microrelief.

A surface with a lower roughness (Figure 7a) that came into contact with the rubber seal of the hydraulic cylinder rod created semi-dry friction because this surface was unable to hold the lubricating film of significant thickness. Grooves of a regular microrelief formed on a working surface (Figure $7 \mathrm{~b}$ ) created friction conditions between the hydrocylinder surface and the rod seal, which are necessary for regular operation.

Thus, the research showed that, apart from reducing the mean value of the surface roughness parameter $R a$ (Figure 8), the technological operation of semi-finish turning significantly worsened the accuracy parameter-the deviation from roundness. High values of deviation from roundness were not eliminated by the technological operation of finishing [32,33]. Additionally, these modes of processing formed an inhomogeneous surface structure. 


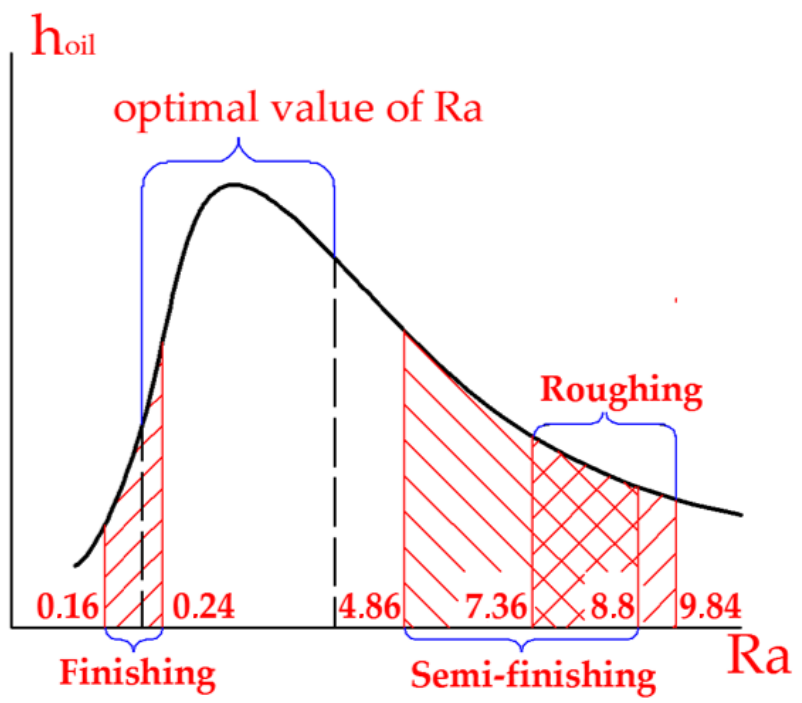

Figure 8. Roughness parameters provided by process operations.

According to the experimental findings [29], the height-related $(R a)$ and pitch-related (S) surface roughness parameters [9] obtained after semi-finish turning satisfied the conditions recommended for this type of coupling. However, the inhomogeneous structure of the liner surface material obtained during this operation and the deep scratches observed in 3D photos of the surface subjected to the finish rolling were local defects that occurred during the liner operation, which would eventually lead to the formation of burrs and loss of tightness within the coupling.

\section{Conclusions}

Analysis of the parameters of roughness $R a$ indicated that, after each technological operation, they gradually decreased. However, as can be seen from the figure, the technological operation of semi-finish turning provided the value of the roughness parameter in a fairly wide range of values from 4.86 to 8.8 , thus partially duplicating the previous technological operation of roughing. As a result, an inhomogeneous surface structure with micro defects was formed, which was confirmed by profilometry data.

The technological operation of grooves of a regular microrelief provided such values of the height parameters of the surface roughness $R a$, which "skip" the optimal value that provides the maximum thickness of the oil film that can hold this surface.

The numerical value of the roughness parameter $R a$ characterizing the standard roughness deviation was found not to provide for an exact estimate of the surface quality because its reduction did not always result from the improved performance of the surface. Additionally, the surface quality was assessed by the Abbott-Firestone curve during the finishing operation.

The quality and service characteristics of internal cylindrical surfaces of hydrocylinder liners were improved by changing technological operations. In particular, semi-finish turning was chosen to provide for the surface roughness parameter $R a$ within $6.3-8 \mu \mathrm{m}$ and the pitch parameter $S$ within $0.4-0.6 \mathrm{~mm}$, as well as the homogeneous surface structure.

The burnishing operation that forms a regular microrelief of type IV (mesh microrelief) was used as a finishing operation. This resulted in a lubricating film of a given size formed on the working surface of the "rod-hydrocylinder liner" tribopair. This recommendation is consistent with the research findings presented in [32].

Author Contributions: Conceptualization, V.D. and P.M.; methodology, V.D.; analysis and validation, V.D. and P.M.; writing, V.D. and P.M.; review and editing, V.D.; supervision, P.M. All authors have read and agreed to the published version of the manuscript.

Funding: This research received no external funding. 
Institutional Review Board Statement: "Not applicable" for studies not involving humans or animals.

Data Availability Statement: The data presented in this study are available on request from the corresponding author.

Conflicts of Interest: The authors declare no conflict of interest.

\section{References}

1. Drogobych Truck Crane Plant. Available online: http://dak.com.ua/eshop/products_goup/4 (accessed on 1 May 2021).

2. Zhang, X.; Wang, G.; Xia, P.; Li, H.-P.; He, M. Finite element analysis and experimental study on contact pressure of hydraulic support bud-shaped composite sealing ring. Adv. Mech. Eng. 2016, 8, 1-9. [CrossRef]

3. Velichko, S.A.; Chumakov, P.V.; Kolomeychenko, A.V. Assessment of technical condition of C series power hydraulic cylinders of mounted hydraulic systems of tractors. Eng. Technol. Syst. 2019, 29, 397-413. [CrossRef]

4. Castro, R.D.M.; Rocha, A.D.S.; Curi, E.I.M.; Peruch, F. A Comparison of microstructural, mechanical and tribological properties of WC-10Co4Cr-HVOF coating and hard chrome to use in hydraulic cylinders. Am. J. Mater. Sci. 2018, 8, 15-26. [CrossRef]

5. Mrochek, Z.A.; Shaturov, H.F.; Zholobov, A.A.; Shaturov, D.H. Progressive methods of shaping the surfaces of hydraulic cylinders. Bull. BNTU 2009, 1, 14-18. (In Russian)

6. Yang, L.; Moan, T. Prediction of long-term fatigue damage of a hydraulic cylinder of a wave energy converter subjected to internal fluid pressure induced by wave loads. Int. J. Mar. Energy 2013, 2, 43-60. [CrossRef]

7. Gamez-Montero, P.J.; Salazar, E.; Castilla, R.; Freire, J.; Khamashta, M.; Codina, E. Friction effects on the load capacity of a column and a hydraulic cylinder. Int. J. Mech. Sci. 2009, 51, 141-151. [CrossRef]

8. Qin, P.-P.; Yang, C.-L.; Huang, W.; Xu, G.-W.; Liu, C.-J. Honing process of hydraulic cylinder bore for remanufacturing. In Proceedings of the 2015 4th International Conference on Sensors, Measurement and Intelligent Materials, Shenzhen, China, 27-28 December 2015; Atlantis Press: Amsterdam, The Netherlands, 2016. [CrossRef]

9. GOST 2789-73. Surface Roughness. Parameters and Characteristics; Standartinform, Publ.: Moscow, Russia, 2018; 6p. (In Russian)

10. DSTU GOST 25142:2009. Surface Roughness. Terms and Definitions; Derzhspozhivstandart of Ukraine, Publ.: Kiev, Ukraine, 2009; 22p. (In Ukrainian)

11. GOST R ISO 4287-2014. Geometrical Product Specifications (GPS). Surface Texture. Profile Method. Terms, Definitions and Surface Texture Parameters; Standartinform Publ.: Moscow, Russia, 2015; 18p. (In Russian)

12. ISO 1302:2002 Geometrical Product Specifications (GPS) - Indication of Surface Texture in Technical Product Documentation. Available online: https://www.iso.org/obp/ui/\#iso:std:iso:1302:ed-4:v1:en (accessed on 9 June 2021).

13. ISO 13565-2:1996 Geometrical Product Specifications (GPS)—Surface Texture: Profile Method; Surfaces Having Stratified Functional Properties-Part 2: Height Characterization Using the Linear Material Ratio Curve. Available online: https://www. iso.org/standard/22280.html (accessed on 9 June 2021).

14. GOST 16514-96. Hydraulic Fluid Power. Hydraulic Cylinders. General Technical Requirements; Izdatelstvo Standartov, Publ.: Minsk, Belarus, 2002. (In Russian)

15. Witenberg, Y.R. Surface Roughness and Methods of Its Evaluation; Sydostroyeniye: Leningrad, Russia, 1971; 108p.

16. Dobrotvorskyi, S.S.; Basova, E.V. Surface Roughness Prediction Methods: Overview. Bull. Natl. Tech. Univ. KhPI Themat. Issue Technol. Mech. Eng. 2010, 41, 23-45. (In Ukrainian)

17. Xiao, M.; Shen, X.; Ma, Y.; Yang, F.; Gao, N.; Wei, W.; Wu, D. Prediction of Surface Roughness and Optimization of cutting parameters of stainless steel turning based on RSM. Math. Probl. Eng. 2018, 2018, 9051084. [CrossRef]

18. Knight, W.A.; Boothroyd, G. Fundamentals of Metal Machining and Machine Tools, 3rd ed.; CRC Press: Boca Raton, FL, USA, 2005; $602 \mathrm{p}$.

19. Lin, S.C.; Chang, M.F. A study on the effects of vibrations on the surface finish using a surface topography simulation model for turning. Int. J. Mach. Tools Manuf. 1998, 38, 763-782. [CrossRef]

20. Thomas, M.; Beauchamp, Y.; Youssef, A.Y.; Masounave, J. Effect of tool vibrations on surface roughness during lathe dry turning process. Comput. Ind. Eng. 1996, 31, 637-644. [CrossRef]

21. Tabenkin, A.N.; Tarasov, S.B.; Stepanov, A.N. Sherokhovatost', Volnistost', Profil'. Mezhdunarodnyy Opyt [Roughness, Waviness, and Profile, International Experience]; Russian Federation, Izd-vo Politekhn. Un-ta: Saint Petersburg, Russian, 2007; 136p. (In Russian)

22. Davidescu, D.A.; Pavelescu, D.; Tudor, A.; Seiciu, L.P. The importance of accuracy values of the abbottfirestone parameters curve for fractal and nonfractal calculus. In The Annals of University Dunărea de Jos of Galaţi-Fascicle VIII: Tribology; 2004; pp. 3-6. Available online: https://www.academia.edu/24590282/The_Importance_of_Accuracy_Values_of_the_Abbott_Firestone_ Parameters_Curve_for_Fractal_and_Non_Fractal_Calculus (accessed on 9 June 2021).

23. Salcedo, M.C.; Coral, I.B.; Ochoa, G.V. Characterization of surface topography with Abbott Firestone curve. Contemp. Eng. Sci. 2018, 11, 3397-3407. [CrossRef]

24. Lipa, Z.; Tomaníčková, D. Utilisation of abbott-firestone curves characteristics for the determination of turned surface properties. Ann. Fac. Eng. Hunedoara-Int. J. Eng. 2011, 9, 223-226.

25. Laheurte, R.; Darnis, P.; Darbois, N.; Cahuc, O.; Neauport, J. Subsurface damage distribution characterization of ground surfaces using Abbott-Firestone curves. Opt. Express 2012, 20, 13551-13559. [CrossRef] [PubMed] 
26. Amine, H. Effect of cutting variables on bearing area curve parameters (BAC-P) during hard turning process. Arch. Mech. Eng. 2020, 67, 73-95. [CrossRef]

27. Kubatova, D.; Melichar, M. Roughness evaluation using Abbott-Firestone curve parameters. In Proceedings of the 29th International DAAAM Symposium, Zadar, Croatia, 24-27 October 2018; pp. 467-475. [CrossRef]

28. Aftanaziv, I.S.; Kusyi, Y.M. Analysis and vibration of the optimal final operations of the technological process of preparing pre-built cylindrical parts. Bull. Lviv Polytech. Natl. Univ. 2000, 412, 3-11.

29. Schneider, Y.G. Service Properties of Parts with Regular Microrelief, 2nd ed.; Mashinostroenie: Leningrad, Russia, 1982; 248p. (In Russian)

30. Yamnikov, A.S.; Rodionova, E.N.; Matveev, I.A. Influence of technological inheritance on accuracy of assembly of axisymmetric shells. In Proceedings of the 6th International Conference on Industrial Engineering (ICIE 2020); Radionov, A.A., Gasiyarov, V.R., Eds.; Lecture Notes in Mechanical Engineering; Springer: Berlin/Heidelberg, Germany, 2021; pp. 130-140. [CrossRef]

31. Kryvyi, P.D.; Dzyura, V.O.; Tymoshenko, N.M.; Krypa, V.V. Technological heredity and accuracy of the cross-section shapes of the hydro-cylinder cylindrical surfaces. In Proceedings of the International Conference on Materials and Processing and the 42nd North American Manufacturing Research Conference, Detroit, MI, USA, 9-13 June 2014; p. 2, Paper No. MSEC2014-3946. [CrossRef]

32. Zhang, Y.; Zeng, L.; Wu, Z.; Ding, X.; Chen, K. Synergy of surface textures on a hydraulic cylinder piston. Micro Nano Lett. 2019, 14, 424-429. [CrossRef]

33. Pawlus, P.; Reizer, R.; Wieczorowski, M.; Krolczyk, G. Material ratio curve as information on the state of surface topography-A review. Precis. Eng. 2020, 65, 240-258. [CrossRef]

34. Dzyura, V.O.; Maruschak, P.O.; Zakiev, I.M.; Sorochak, A.P. Analysis of inner surface roughness parameters of load-carrying and support elements of mechanical systems, International. J. Eng. Trans. B Appl. 2017, 30, 1170-1175. [CrossRef]

35. Konovalov, S.; Ivanov, Y.; Gromov, V.; Panchenko, I. Fatigue-induced evolution of AISI 310 s steel microstructure after electron beam treatment. Materials 2020, 13, 4567. [CrossRef] [PubMed] 